\title{
ESSAY
}

\section{The Sweet Science, Legally Speaking (Professional Boxing)}

\author{
JEFFREY S. FRIED \\ Fried \& Company, P.C.
}

I will never forget that time in 1988 when I first became involved in representing interests in the professional boxing industry, and the response from one well established boxing promoter and attorney, "What could a lawyer from Washington, D.C. possibly know about boxing. . .?"

During these subsequent 16 years I have concluded that professional boxing, like any business industry, requires an extensive commercial and legal knowledge of the industry, a familiarity with the applicable rules and regulations of the governing bodies and an understanding of, and relationship with, the key players. This applies whether you are involved in the transactional aspects of the boxing industry, the legislative and regulatory process, or the all too frequent litigation end.

While the significance and contributions of the various parties involved in a boxing event are plentiful, ultimately it is the professional athlete that possesses (or doesn't possess) the status to attract a paying audience and, as discussed below, the unique marquee status to garner a large "pay-per-view" television audience and the corresponding revenue. The single largest revenue item in a boxing promotion is customarily derived from the domestic television broadcast. The two most prominent broadcast outlets are Showtime (owned by Viacom) and HBO (owned by AOL/Time Warner). Therefore, separate and apart from the eccentric dynamics associated with every professional boxing transaction, and the equally eccentric personalities, at the core remains the epitome of corporate America, namely super media giants AOL/Time Warner and Viacom. Contracts involving these media conglomerates, the professional boxers, venues, international broadcast networks, sponsors and the ancillary matters associated with a boxing promotion involve a variety of legal considerations, some of which are addressed in this essay. 
Unlike many other sports industries and, in part, attributable to the lack of a single governing body, professional boxing is as rich in the courtroom as the action that transpires within the $20 \times 20$ foot ring!!

\section{A. PRACTICAL CONTRACTUAL SAFEGUARDS}

During the course of their careers professional boxers become a party to numerous contracts. In addition, there are commercial arrangements involving third parties (for example, promoters, television networks, venues, event sponsors, etc.) that directly affect a boxer's career development and corresponding financial considerations. Quite frankly, these basic matters apply to any professional athlete or entertainer and, more broadly, to any individual that is a party to a personal services or similar contractual arrangement.

Before addressing specific forms of contractual understandings within the boxing industry, certain practical safeguards should apply as follows:

\section{Professional Representation.}

Each boxer should be represented by an attorney or advisor representing solely the interests of the boxer, clear of conflicts with the other contractual party and third parties associated with the commercial dealings of the boxer. Conflicts of interest in the boxing industry could be the subject of a separate law school class. In this regard, note the following proposed language for inclusion in a law firm's engagement letter addressing a potential conflict of interest:

It is understood that this Firm represents other boxing interests, including Accordingly, any matters that may be undertaken by this Firm on your behalf must be clear of any conflict (or even the appearance thereof) with such clients. Accordingly, issues may arise whereby this Firm may not be able to represent you and we will promptly notify you in writing of any conflict (or appearance thereof) that might exist with regard to a matter you desire to be undertaken by this Firm. At this time there does not appear to be either an actual conflict or the appearance of a perceived conflict of interest in undertaking this representation. 


\section{Understanding of Contractual Relations.}

The boxer, and his representative, must have copies of all agreements to which the boxer is a party (or third party agreements applicable to the boxer's career) to ensure that all parties are in full compliance with their respective obligations. This sounds obvious, but is not always the case. All too often it becomes necessary to formally communicate with (and legally threaten) third parties to simply furnish an executed copy of the agreement to which the professional boxer is contractually bound.

\section{Communication.}

It is imperative that a professional boxer, through his representative or on his own behalf, has ongoing communication with the other contractual parties to ensure that issues are addressed in a timely manner and on a continuous basis (and in writing, where appropriate). As with all businesses, and particularly professional sports, a much greater international marketplace currently exists. Therefore, it is commonplace for there to be translators and for all relevant agreements and communications to be translated into the native language of the applicable parties. When Sharmba Mitchell agreed to challenge undisputed Junior Welterweight Champion Kostya Tszyu in Mr. Tszyu's hometown of Moscow in February, 2004, the travel, accommodations, customs and other logistical aspects associated with this international event seemingly required as substantial time and attention as the training camp undertaken by Mr. Mitchell in preparation for the Championship Bout. A complete team was established in Moscow to facilitate matters for the traveling U.S. "entourage," including chefs, translators, security and embassy officials to ensure that all matters were properly in order for a mere boxing event.

\section{Term of Relationship.}

A professional boxer must be mindful of the length of the term of his contractual relationships. Circumstances in life, let alone boxing, constantly change and the boxer must be aware of the timeframe he is obligating himself to another party in furtherance of his professional career. 


\section{Compliance Requirements.}

Professional boxers, managers and promoters (and possibly, in the future, television networks) are licensees of a governing athletic or boxing commission (for example, the Nevada State Athletic Commission) and, therefore, have regulatory responsibilities to ensure that they are in compliance with such license. All parties should be fully informed of the applicable athletic commission requirements with regard to maintaining their license. ${ }^{I}$

\section{B. MUHAMMAD ALI BOXING REFORM ACT-IN A NUTSHELL}

The Muhammad Ali Boxing Reform Act (2000) ("Ali Act") is the first federal law passed to reform perceived anti-competitive and corruptive business practices in the professional boxing industry. The Ali Act was introduced by Senator John McCain on June 29, 1998 and signed into law on May 26, 2000. The Ali Act requires a promoter to disclose all revenue sources from a particular boxing event, the expenses being deducted from a boxer's remuneration for participation in such boxing event and mandates other commercial, regulatory and health related safeguards intended to prevent perceived corruptive business practices within the boxing industry. Certain significant requirements of the Ali Act include:

a. A one-year limit on promotional rights that a promoter may require a boxer (or the boxer's current promoter) to provide in those situations where the boxer would otherwise be denied the opportunity to compete in a boxing match, i.e., "unless you give me options to promote your future bouts, you don't get to participate in this bout against my fighter!!" (15 U.S.C. \$6307(b), 2003).

b. Promoters must disclose pertinent information to the supervising athletic commission: copies of their contracts with the boxers; fees and charges they impose on the boxers; payments made to sanctioning organizations (discussed below); any proposed reduction in the contractual purse remitted to the boxers as well as revenues derived by the promoter from the event (15 U.S.C. $\$ 6307(\mathrm{e})$ ). While not addressed in the Ali Act, certain non-direct financial items should also

1. For example, during 2002 the licensing of Mike Tyson within the State of Nevada became both a media circus and a political quagmire. While receiving a boxing license from an athletic commission is a relatively standard procedure (subject, of course, to issues of health, age and other safety considerations as well as the approval process inherent in the matchmaking) the reissuance of Mr. Tyson's boxing license became critical in the efforts to promote future bouts for Mr. Tyson in the State of Nevada and the corresponding substantial revenues that would be derived therefrom. 
be considered; for example, barter arrangements, multi-bout site and/or domestic and international broadcast arrangements incorporating other boxing events involving the promoter (but not necessarily that particular boxer). Attached as Annex A are examples of Disclosure Forms to be provided to the athletic commission and boxers pursuant to the provisions of the Ali Act.

c. Promoters are generally barred from having a financial interest with the manager of a boxer (15 U.S.C. $\S 6308){ }^{2}$

d. For the safety of the boxers, each state athletic commission must reciprocally enforce the suspension of boxers by other state athletic commissions due to injuries or misconduct (15 U.S.C. $§ 6309$ (c).

e. Individuals knowingly violating the Ali Act can face up to one year in jail or fines up to $\$ 100,000$ (larger fines for major events). State Attorneys General can initiate civil actions and injunctions under the Ali Act, while boxers can initiate civil actions (15 U.S.C. $\$ 6309(b)$ ).

f. Sanctioning organizations (the entities that generally issue ratings of boxers and approve world championship boxing matches) must timely respond to protests from boxers regarding their rankings and provide justification for changes the sanctioning organization makes in its rankings. On an annual basis, sanctioning organizations must disclose their ratings policies and bylaws, the fees they charge boxers

2. Relating to this particular issue, New York Court documents reflect numerous relationships whereby Don King was the promoter of a particular boxer, and Carl King (Don's son) was the manager of that same boxer. It is generally the responsibility of the manager to negotiate, on behalf of the boxer, with the promoter in order to maximize the boxer's financial arrangements for bouts in which the boxer participates. In certain of these circumstances the Court documents further disclose that Carl King had borrowed hundreds of thousands of dollars from his father which remained outstanding during the timeframe of such promotional/managerial relationship with the boxer, which counsel argued created a conflict of interest and, at a minimum, clouded the ability of Carl King to negotiate at arms length with his father on terms that would otherwise have been in the best interests of the boxer.

In a separate case with similar conflict of interest considerations, in December, 2003 Don King settled a lawsuit filed by retired professional boxer Terry Norris by agreeing to remit $\$ 7.5$ million to Mr. Norris, who alleged that due to a conflict of interest between Mr. King and Mr. Norris' manager between the period June 1994 through April 1997 the purse amounts remitted to Mr. Norris were substantially less than fair market value, and what would otherwise have been remitted in an arms length transaction. It was a stipulated fact in that case that Mr. King had "loaned" Joseph Sayatovich, the manager of Mr. Norris, approximately $\$ 300,000$ during the same timeframe in which Mr. King was the promoter of Mr. Norris. One of the apparent triggering events resulting in the financial settlement by Mr. King was the request to the Court from the jury foreman, during jury deliberations, for a calculator (presumably, to calculate the damages incurred by Mr. Norris based, at least in part, upon the aforementioned conflict of interest). 
and the names of their members who decide the rankings. These rankings established by the sanctioning organizations are historically important in determining which boxer receives an opportunity to challenge for a World Championship and, in certain instances, the compensation the boxer receives for participating in the World Championship bout (and potentially subsequent World Championship defense bouts) (15 U.S.C. $\$ 6307(d)$ ).

The actions of sanctioning organizations have been the subject of enhanced scrutiny, and apparently rightfully so due to recent acknowledged abuses. For example, due to the corrupt business practices within the International Boxing Federation, generally recognized as one of the top four sanctioning organizations, a Receiver was appointed by Judge William Bissell of the United States District Court (Newark, NJ) to oversee IBF operations. The former President of the IBF, Robert W. Lee, was sentenced to a prison term of 22 months for accepting payoffs from promoters in exchange for higher rankings for certain boxers and other illegal actions (United States $v$. Robert W. Lee, 2001).

Another major sanctioning organization, the World Boxing Council, filed for bankruptcy protection following a judgment ordering the WBC to pay $\$ 30,000,000$ in damages to a professional boxer. In Graciano Rocchigiani v. $W B C$, Inc. (2001), the Court ruled that boxer Rocchigiani should have been declared the WBC Light Heavyweight Champion based upon defeating Michael Nunn in what was characterized as a Light Heavyweight Championship Bout for the vacant WBC title. However, the WBC declared Rocchigiani the so-called "Interim" Light Heavyweight Champion and designated the previous title holder and marquee athlete (Roy Jones, Jr.) as a "Champion in Recess," adversely affecting the Championship status (and earning power) of Rocchigiani. Because Mr. Jones did not defend his title against the mandatory number one contender, the "vacant" vs. "champion in recess" controversy ensued. The Court found that there was a breach of contract by the WBC in the application and enforcement of its rules, and awarded damages of $\$ 30,000,000$ to Rocchigiani (Graciano Rocchigiani, 2001, p. 532).

The consequence is that such authority within a sanctioning organization has a material (and potentially irreparable) impact upon a boxer and his ability to become a World Champion and to receive the corresponding financial benefits associated with World Championship status. 


\section{TYPES OF AGREEMENTS}

There are a variety of agreements inherent in the boxing industry and generally applicable to a professional boxer throughout his professional boxing career, including -

1. Promotional Agreement

2. Bout Agreement

3. Television License Agreement

4. Site Agreement

5. Management/Consulting/Advisory Agreement

6. Trainer Agreement

7. Sponsorship Agreement

8. Closed Circuit Agreement

\section{Promotional Agreement.}

In many instances, the promotional agreement represents the most significant contractual arrangement for a boxer. It is the responsibility of the promoter to provide the boxer with an opportunity to participate in a minimum number of bouts during the term of the promotional agreement and to remit, generally, a minimum level of compensation for the boxer's participation in each bout. The boxer's performance in the ring, the manner in which he conducts himself outside of the ring and the efforts of his promotional and (if applicable) management team are important components in enhancing the marketability of the boxer and, correspondingly, the level of the boxer's purses (i.e., characterization of a boxer's compensation for participating in boxing matches).

Important items to be considered by a boxer (and the promoter) when entering into a promotional agreement include the following:

\section{a. Term.}

The length of the term of the promotional agreement is important for both parties in connection with their respective obligations. Many jurisdictions provide limitations on the maximum term permissible in personal service agreements and certain athletic commissions likewise impose maximum terms for a promotional agreement. For example, California Labor Code \$2855(a) (2003) provides that a contract to render personal services may not be enforced against the employee beyond seven years from the commencement of 
service. On the other hand, New York does not impose a limit on the length of personal service agreements, as contracts providing for perpetual performance have been upheld (See Ketcham v. Hall Syndicate, 1962).

In Oscar De La Hoya v. Top Rank, Inc. (2001, p. 1), the Court held that the Top Rank promotional agreement was void and unenforceable for noncompliance with statutory and regulatory provisions governing arrangements between boxers and their promoters, and for exceeding California's statutory seven-year time limit on contracts for personal services. The Court found that the amendments to the original five year and one month term of the Top Rank/De La Hoya Agreement did not create a "break in privity," and, therefore, De La Hoya had been continuously obligated to provide services to Top Rank for more than seven years (Oscar De La Hoya, p. 23).

Moreover, the California Boxing Commission promulgated a form entitled "Addendum to Promotional Contract," which states that no promotional contract "may exceed three years nor is valid and enforceable until it is submitted to, approved by, and filed with the California Boxing Commission with such Addendum attached." Since the procedural requirements of filing the Agreement and the amendments with the California Boxing Commission were not followed by Top Rank, the contract with De La Hoya was ruled void and unenforceable. Ironically, and somewhat commonplace in professional boxing, is that following such contentious litigation and substantial media and public relations tactics utilized by each of Top Rank and Mr. De La Hoya, the parties entered into a new agreement and millions of dollars were made by each in the promotion of Mr. De La Hoya boxing events following such reconciliation, and only one year after the Court decision in favor of Mr. De La Hoya.

The accomplishments, current professional status and age of a boxer are significant considerations in determining whether the promotional term is reasonable. For example, a promoter would generally need more time to assist in promoting and developing a young, less developed boxer and, from a commercial viewpoint, the promoter would need sufficient time to receive a reasonable return on its investment for such efforts and expense.

Note the following material provisions customarily included within a promotional agreement relating to the term:

The Term of this Agreement ("Term") shall commence on the date of full execution and continue for four (4) years, unless terminated sooner or extended further pursuant to this Agreement. In the event Promoter secures a television contract on behalf of Boxer with a 
Network (as defined), then it is agreed that the Term of this Agreement shall be automatically extended to correspond to the expiration of such Network contract, assuming such Network contract term extends beyond the original Term of this Agreement, and subject to the applicable rules and regulations regarding the maximum duration of promotional agreements.

In the event that Boxer at any time during the Term shall have been declared the loser of any Bout by the athletic commission then, in Promoter's sole discretion, Promoter shall have the right, but not the obligation, to terminate this Agreement. Further, the Promoter shall have the right to terminate this Agreement without further obligation to Boxer in the event of the following: (i) Boxer shall fail to honor any material obligation under this Agreement, or pursuant to rules of the athletic commission; (ii) Boxer becomes unable to compete at a professional level by reason of age, single or cumulative injury, or any career ending injury; (iii) Boxer tests positive for any controlled substance, and/or unlawful drugs or substances and is suspended by the athletic commission or (iv) Boxer fails any physical examination or test required for eligibility to participate in any Bout pursuant to this Agreement, or the rules of the athletic commission.

\section{b. Number of Bouts.}

The promoter generally has an obligation to provide/offer a minimum number of bouts during each year of the term. For an up and coming boxer it is important to remain active and receive television exposure in his developing stages as an "undercard" participant, i.e., comparable to an opening act in a musical concert. Once a boxer reaches main event status (comparable to the headliner in a concert) the number of bouts will likely decrease based on economic realities, such as broadcast budgets, suitable high level opponents and the necessary lead time to promote each event.

\section{c. Purses.}

Promotional agreements customarily include minimum purses that the boxer will receive for participation in bouts under the agreement. For developing professional boxers the purses usually escalate depending upon the number of rounds in the bout and the television medium broadcasting the bout. For well established boxers, world champions and/or popular boxers with a large fan base, the purses are generally determined by the television medium 
and, in certain circumstances; the financial arrangements may include an allocation of net event promotional revenues between the promoter and the boxer. Each of these items, nevertheless, should be fully negotiated between the parties. The bout agreement (referenced in Item 2 below) is required to specifically set forth the procedure for any deductions from the boxer's purse (e.g., training, purse advances, sanction fees, family travel, etc.), and such deductions must be in compliance with the Ali Act and the rules of the applicable athletic commission. It is quite common for the few select marquee boxers to include in their compensation arrangements a formula whereby they either receive a financial upside based upon pay-per-view home sales or an overall allocation of net event promotional revenues between the promoter and the boxer, e.g., $80 \% / 20 \%$ split of net event promotional revenues (in favor of the boxer).

Grant of Exclusive Promotional Rights. Boxer hereby grants to Promoter the exclusive ${ }^{3}$ right to promote the professional boxing matches ("Bouts") to be engaged in by Boxer and to be promoted by Promoter or its designee during the Term. The promotional rights shall include, without limitation of the foregoing grant, all rights in perpetuity required to stage and sell tickets of admission to the Bouts, to commercialize and market all ancillary rights (including, but not limited to, worldwide rights to broadcast, telecast, record and film the Bouts for exhibition in any and all media including, but not limited to, motion picture, radio, television - whether live or delayed, interactive, home or theater, pay-per-view, satellite, closed circuit, cable or subscription - telephone, computer, internet, CD-Rom, video and audiocassette, photograph whether currently existing or subsequently developed). Promoter shall have the exclusive right to obtain in its name copyright or similar protection in the United States and all other countries of the World where such protection is available. Promoter shall market and commercialize all such rights in the Bouts in a commercially reasonable manner.

3. In certain jurisdictions (e.g., Nevada) "exclusive" promotional agreements are not permissible. For example, Section 467.112(2) of the Nevada Administrative Code (2003) states "[an] agreement which provides that an unarmed combatant must fight exclusively for one promoter or at the option of the promoter is prohibited." In these circumstances to avoid "exclusivity" a provision is generally included within the promotional agreement permitting the boxer to engage in so-called "other bouts" for other promoters; provided, however, that such other bouts may not occur within a stated timeframe associated with a bout otherwise contemplated to be promoted for the boxer, and in certain circumstances prohibits such "other bout" to be televised. 
Bouts and Purses. (a) Promoter shall provide the following Bouts and cause Boxer to be paid the following minimum amounts:

Contract Year Minimum \# of Bouts Guaranteed Annual Compensation $1 / 1 / 04-12 / 31 / 04$ 4 $\$ 500,000$

$1 / 1 / 05-12 / 31 / 05$ 3

$\$ 750,000$

$1 / 1 / 06-12 / 31 / 06$ 2 $\$ 1,000,000$

$1 / 1 / 07-12 / 31 / 07$ 2

$\$ 1,500,000$

(b) Concurrently with execution of this Agreement, Promoter shall remit to Boxer a non-refundable signing bonus of $\$ 50,000$.

(c) In addition to the above compensation, Promoter shall remit the following training allowances to Boxer in connection with the Bout(s):

Purse

Up to $\$ 150,000$

Between $\$ 150,001$ and $\$ 750,000$

In excess of $\$ 750,000$
Training Allowance

$\$ 20,000$

$\$ 40,000$

To be negotiated in good faith

\section{d. Promotional Plan.}

The boxer and his representative should insist that the promoter attach to the agreement a promotional plan intended to further the professional boxer's career (which should be updated periodically). As with a recording label, the promoter should undertake an overall marketing plan to enhance public and media awareness of the boxer to complement opportunities and accomplishments within the boxing ring. In too many instances the understandings between the parties regarding the plans for the boxer are based upon informal oral discussions, and it is important for both parties to have a clear understanding of the promotional plan to be implemented by the promoter and the boxer. The language in the agreement regarding the minimum number of bouts and minimum compensation during the term are simply contractual requirements of the promoter. The development plan involving particular opponents, television exposure and participation as an undercard boxer on an otherwise significant event (e.g., major heavyweight championship bout) are all important aspects in maximizing the commercial opportunities for the boxer and the development of the boxer's career. These are matters that are not customarily included within a promotional agreement; however, before the boxer commits to a promoter for a stated period of years 
there should be a complete understanding as to their mutually agreed upon development plan for the boxer.

Both parties must have specifically delineated responsibilities (e.g., boxer shall fully cooperate in reasonable promotional and media events, properly prepare and give his best efforts in the boxing event, etc.) to provide the greatest likelihood of successfully implementing a promotional plan and enhancing the boxer's career. There are obviously no assurances as to the boxer's development and success based upon circumstances outside of everyone's control; however, it is important that there be a collective written agreement as to the direction of the professional boxer's career. This is critical inasmuch as a professional boxer has a limited timeframe in which to earn a livelihood. Conversely, the promoter has a limited timeframe in which to receive a commercial benefit through its promotional services and (in many instances) funding in support of the professional boxer's career development.

Publicity and Promotion. Boxer agrees he will cooperate and assist in publicizing, advertising and promoting the Bout(s), and he will appear at and participate in a reasonable number of joint and/or separate press conferences, interviews (before and after a Bout) and other publicity or other appearances (all of which may be telecast and recorded) at times and places designated by Promoter. Boxer further agrees to cooperate with any sponsors of the Bout(s) and to post advertising materials at the training camp of Boxer used in connection with publicity or advertising of such sponsors and to participate in reasonable advertising requests of such sponsors (such advertising shall apply only to the Bout). Boxer further agrees that the training sessions of the Boxer at the site of each Bout shall be open to the public if Promoter reasonably so requests.

Courts have been faced with the issue of determining the validity of promotional agreements between promoters and boxers. For example, in Lewis vs. Rahman (2001), promoter Cedric Kushner Productions, Ltd. asserted that it had a continuing contractual right to promote the boxing matches of Hasim Rahman following his victory against World Heavyweight Champion Lennox Lewis in South Africa. The Kushner/Rahman Promotional Agreement had a two-year term, which had otherwise expired. The agreement granted Kushner an irrevocable option to extend the term of the agreement for two years upon a payment of $\$ 75,000$. Following the April 19, 2001 Championship Bout in which Rahman defeated Lewis, Kushner exercised the option to extend the term of the agreement for two years and remitted by check, in South Africa, the required $\$ 75,000$ payment. Despite such actions by Kushner and the 
language of the promotional agreement, on May 9, 2001 Rahman entered into an exclusive promotional agreement with Don King Productions, Inc. (and to add to the drama associated with professional boxing, it was asserted that Don King remitted a $\$ 500,000$ signing bonus to Rahman in a New York hotel room, consisting of cash in a duffle bag!). Kushner filed suit to have the Court uphold its promotional agreement with Rahman and for damages against Don King Productions for tortuously interfering with its promotional agreement with Rahman. Unfortunately for Kushner, the Court ruled that following the expiration of the promotional agreement, something more than the mere receipt of a check was necessary to revive and extend the agreement, despite the option language. An expressive waiver of timeliness and a clear intention to extend the promotional agreement was required (Lewis, 2001, p. 235). Nevertheless, under a separate Addendum to the original Lewis-Rahman Bout Agreement, Kushner possessed the right to promote Rahman in the rematch with Lewis and the Court determined that Kushner's exclusive right to promote Rahman extended only to that single subsequent rematch bout.

The end result of such litigation was a settlement between Don King Productions and Kushner whereby King promoted the professional boxing career of Rahman and remitted a payment to Kushner of $\$ 2$ million. ${ }^{4}$

In Don King Productions, Inc. v. Douglas (1990a), the enforceability of a promotional agreement was again before the Court. Following his victory against Mike Tyson on February 11, 1990 in Tokyo, Japan, James "Buster" Douglas attempted to be released from his contract with Don King Productions in order to negotiate a more favorable agreement, King brought a breach of contract claim against Douglas. In his defense, among other claims, Douglas asserted that his promotional contract with King was unconscionable. The Court found that a determination of unconscionability requires a showing that a contract was both procedurally and substantively unconscionable when made (Don King Productions, Inc., 1990a, p. 780). In part, since competent counsel represented Douglas at the time of the contract formation, the Court ruled against Douglas.

It is important to note that a promoter generally does not have a fiduciary responsibility to a boxer. In Don King Productions, Inc. v. Douglas (1990b), however, the Court noted that while a fiduciary duty would not customarily arise from a straightforward contractual promotional arrangement, a fiduciary relationship could exist under certain contractual circumstances. For example, a fiduciary relationship might exist between a promoter and the boxer if the 
boxer could demonstrate that the promoter had violated "the very limited issue of trust a boxer reasonably reposes in a promoter" (Don King Productions, Inc., 1990b, p. 769). The existence of a fiduciary relationship would depend on whether the parties, through the past history of the relationship and their conduct, had extended the relationship beyond the limits of the contractual obligations (Don King Productions, Inc., p. 770).

\section{Bout Agreement.}

The bout agreement is entered into between the promoter of a particular boxing event and an individual boxer participating in a bout included within the overall event (generally comprised of between six and eight bouts). Each athletic commission has its own form of bout agreement that must be signed by the promoter and the boxer and filed with the athletic commission prior to the bout, inasmuch as it is the bout agreement that governs the commercial understanding for such boxer's participation in the boxing event. Attached as Annex B is the form of Bout Agreement required to be filed with the Nevada State Athletic Commission.

The bout agreement will contain the purse and other remuneration being remitted to the boxer, and the deductions to be applied against the purse. The following are certain of the material provisions contained within a customary bout agreement:

Boxer will engage in a boxing contest with [opponent] scheduled for twelve (12) rounds to a decision ("Bout") to be broadcast domestically on Network and internationally. The maximum weight for such Bout shall be 140 pounds. The Bout is scheduled to be held on March 6, 2004 at in Las Vegas, NV. The Bout will be conducted and the officials shall be designated in conformity with the rules and regulations of the athletic commission and of such international governing body that may sanction the Bout.

As base compensation for the rights granted to Promoter and for the services and the performances required of and to be rendered by Boxer, Boxer shall receive, upon completion of the Bout, the purse of One Million Dollars $(\$ 1,000,000.00)$, together with a training allowance of $\$ 50,000,(\$ 25,000$ of such training allowance payable concurrently with execution of this Agreement and the balance thirty days thereafter). Promoter may deduct and withhold from the purse only such sums as are necessary for payment of Boxer's share of the applicable athletic commission fees, sanction fees and preauthorized 
expenses and in compliance with the rules of the athletic commission and the Ali Act.

(Assuming pay-per-view event). In addition to the above base compensation, Boxer shall receive an upside based upon pay-per-view home sales ("Upside"). The Upside for the Boxer shall be $\$ 3$ for each pay-per-view home sale in excess of 200,000 homes. The pay-perview home sale reports generated by Network shall be deemed controlling with regard to determining the number of pay-per-view home sales.

\section{Television License Agreement.}

The television license agreement is entered into between the broadcaster (such as HBO, Showtime, Fox, ESPN, Telemundo) and the promoter. The broadcaster remits a license fee to the promoter in exchange for the rights to the exclusive domestic live broadcast of the event. The domestic license fee generally comprises the most substantial element of the overall event revenues received by the promoter and becomes the basis for determining the purses to the boxers, and to satisfy various other event/promotional expenses (e.g., marketing, insurance, travel, etc.). In addition to the domestic television license fees, many events generate revenues from the broadcast on international networks, depending on the marketability (and nationality) of the boxers and the particular event. Nevertheless, as noted above, all event revenues must be disclosed to the boxer consistent with the requirements of the Ali Act.

The premium domestic cable networks (i.e., HBO and Showtime) have historically entered into multi-bout agreements with select popular boxers (e.g., Roy Jones, Shane Mosley, Mike Tyson), whereby the boxer engages in boxing matches solely on their network in consideration for guaranteed bouts and license fees during the term of the agreement, e.g., minimum of two bouts per year for four years at escalating license fees (customarily including extension provisions or matching rights upon expiration and termination rights in the event of a loss). These multi-bout agreements are becoming somewhat less common due to reduced boxing budgets at the premium cable networks and issues relating to the level of opponents for such contractually committed boxers. 


\section{Site Agreement.}

A site agreement is entered into between the venue for the event (e.g., a Las Vegas casino hotel) and the promoter. The promoter agrees to promote a boxing event, or a series of boxing events, and the site provides the venue and may remit a guaranteed fee, so-called "site fee," for the staging of the event, as well as other mutual obligations between the parties. In addition to the site fee, customarily included within a site agreement is an allocation of complimentary rooms and meals (for the promotion team, the boxers and their "entourages"), complimentary tickets for the promoter and the boxers, an agreed upon budget to market the boxing event within the region and media and promotional appearances by the boxer.

Promoter shall promote the Event at the Site on Saturday, March 6, 2004. The Event shall be telecast live on the Network. The live telecast shall commence at or about 7:00 pm, PST. The Event shall consist of the Main Event (as defined) and a sufficient number of undercard bouts to comply with the requirements of the athletic commission.

Promoter shall provide at its expense the following: the services and participation of the Boxers; purse and expense payments (including travel) due to the Boxers; insurance for all Boxers and other ring personnel as may be required by the athletic commission; officials' fees and expenses, transportation and lodging, including officials, referees, judges and attending physicians. .."

Site shall provide at its expense the following: use of the Arena commencing not later than 8:00 am on the day preceding the Event and terminating at midnight on the day of the Event; building staff and facilities as customarily provided by Site for events of this type, including security, ushers, set-up, break-down, clean-up, restoration, electricity and public address system. .."

As full compensation for the rights granted to Site and services to be performed by Promoter under this Agreement, Site shall pay Promoter a guaranteed amount of Two Million Dollars $(\$ 2,000,000)$ (the "Guaranteed Amount") plus a share of Net Receipts (as defined). The Guaranteed Amount shall be paid to Promoter by certified check on the first banking day following the conclusion of the Event.

In addition to the above compensation, Site shall pay Promoter a share of Net Receipts as follows: Site shall retain the first $\$ 2,500,000$ of Net Receipts; and Promoter and Site shall share all remaining Net Receipts 
on a $75 \% / 25 \%$ basis. Site shall pay Promoter eighty percent $(80 \%)$ of Promoter's share of Net Receipts as reasonably estimated by Site within five (5) business days following the Event and the remainder of Promoter's share of Net Receipts within fifteen (15) business days after the Event and completion of the accounting for the Event.

\section{Management/Consulting/Advisory Agreements.}

In many circumstances a boxer will retain a manager or other advisor to represent his professional interests. As discussed above, a promoter generally does not have a fiduciary responsibility to a boxer. It is generally the promoter's responsibility to promote the boxer's career through the staging of boxing events and to enhance the awareness of the professional boxer so that substantial purses can be earned by the boxer and commensurate event profits realized by the promoter. However, it is generally not the promoter's responsibility to ensure that the boxer is protected in all aspects of agreements between the promoter, the boxer and various third parties. Therefore, there is usually the need for an attorney and/or manager to represent the boxer's interest.

A customary management/advisory agreement provides for a percentage (customarily ranging from $10 \%-33 \%$ ) of the boxer's purses to be remitted to the manager. In these types of agreements, there should be an absolute understanding as to the expense responsibilities in connection with training, marketing and public relations, and what expenses are the responsibility of the boxer (for example, the trainer and other corner persons' fees). Too many management agreements in the personal services area provide vague financial expense responsibilities resulting in misunderstandings among the parties.

Various jurisdictions have requirements pertaining to such management agreements, including the length of the term and the maximum percentage that can be received by the manager. For example, pursuant to Nevada Administrative Code (NAC) Chapter 467, Section 102(1) (2003), the Nevada State Athletic Commission will not honor a contract between a manager and a boxer if the term of the contract is for a period of more than four years. In addition, NAC Chapter 467, Section 102(6) (2003) prohibits a manager from participating separately or collectively in more than $331 / 3 \%$ of the earnings of a boxer. Moreover, the Ali Act and rules of many athletic commissions provide for certain "firewalls" to be established between managers and promoters to ensure that there is no conflict of interest between such parties. For example, NAC Chapter 467 Section 104 (2003) provides that promoters are prohibited from acting as managers of boxers and from holding certain 
financial interests. An unarmed combatant may not have a promoter or any of its members, stockholders, officials, matchmakers or assistant matchmakers:

a. act directly or indirectly as his manager; or

b. hold any financial interest in his management or his earnings from contests or exhibitions (NAC ch. 467, $\S 104,2003$ ).

Boxers should also consider whether their manager or an independent party should handle their finances. In either situation there should be complete accountability (and periodic written reports) to the boxer. It is naturally preferable for all concerned that an independent party administers the boxer's finances from a "checks and balances" perspective. In particular, it is not in the manager's best interest to be responsible for the finances of the professional boxer, or any individual client performing such form of personal services. An independent accountant and/or financial advisor should ideally serve in such capacity to avoid even the appearance of a potential conflict of interest of other impropriety related to the boxer's finances, investments and tax considerations.

\section{Trainer Agreement.}

Written agreements between a boxer and his trainer are not common within the boxing industry, except for the more renowned boxers and where the purse amount is generally quite substantial. In certain instances, a promoter may enter into a contract with a trainer whereby such trainer agrees to undertake training responsibilities on behalf of various boxers that have entered into promotional agreements with such promoter.

Unfortunately, litigation in the boxing industry is becoming a relatively frequent occurrence (and, in many circumstances, a commercial weapon), including disputes between a trainer and boxer. ${ }^{5}$ In Rooney v. Tyson (1998), the jury rendered a $\$ 4,415,615$ verdict to trainer, Kevin Rooney, for breach of an oral agreement between Rooney and Mike Tyson. An oral personal services contract between a trainer and a boxer to last "for as long as the boxer fights professionally" was found to provide a definite legally cognizable duration (Rooney, 1998, p. 694). The Rooney Court found that only an

5. Substantial efforts have been made to establish a governing body whereby disputes would be the subject of arbitration, similar to proceedings in other professional sports, e.g., Major League Baseball, National Basketball Association. Such efforts continue, and generally are perceived to be a positive development due to the substantial costs associated with litigation and the inability of most individuals and entities within the professional boxing industry to fairly compete/participate in such litigation despite their legal position. 
employment term of an indefinite or undefined duration would trigger the atwill employment presumption (Rooney, p. 688). It reasoned that the at-will presumption was inapplicable because the durational period was capable of being determined (p. 690). Conceding that Tyson's boxing career was not precisely predictable and calculable, the Court nevertheless held that the duration of the commercial relationship was reasonably ascertainable (p. 691).

Trainers (depending upon their credentials and experience) generally receive between $5 \%-10 \%$ of the boxer's purse. Nevertheless, there should be a written agreement between the boxer and trainer regarding such fees and the specific services to be rendered by the trainer, including responsibilities of the trainer during training camp leading up to the bout. And what amounts received by the boxer are subject to the percentage compensation to be received by the trainer? For example, training expenses and certain fees received by the boxer associated with international television broadcasts, separate and apart from his stated purse, may not be included in calculating the trainer's compensation. Naturally, it is prudent to confirm the manner in which such payments are being characterized so that the trainer, or any other party entitled to a percentage compensation, receives their equitable amount.

\section{Sponsorship Agreement.}

Sponsorship support is important both from financial and marketing perspectives. Boxing has generally not been accepted within the mainstream sponsorship categories. For the most part, beer sponsors such as Anheuser Busch, Miller, Corona, etc., have sponsored professional boxing. On occasion, large scale pay-per-view events (depending upon the marquee status of the main event participants) have created ancillary sponsorship opportunities. The reasons for the lack of broad based sponsorship interest is the perception that the professional boxing fan is within a limited demographic (buying) group and, for better or worse, non consumer-friendly controversy continues to be an integral part of professional boxing. While such controversy may enhance the live gate and television ratings for a particular boxing event, this controversy does not necessarily reconcile with the marketing objectives of potential sponsors.

Promoter shall conduct the Event on Saturday, March 6, 2004 at in Las Vegas, Nevada. Sponsor shall be the principal

sponsor of the Event. Promoter may grant supporting sponsorship rights to third parties, provided that no such third party manufactures, distributes or sells alcoholic or non-alcoholic malt beverages, bakery products or snack foods. 
Sponsor shall remit to Promoter a fee of $\$ 150,000$, payable within seven days following the Event.

The Sponsor trademarks, label designs, product identification and related artwork shall remain the property of Sponsor. All rights in the Trademarks under trademark or copyright law or other property rights shall inure to the benefit of and be the exclusive property of Sponsor. Sponsor grants to Promoter, the Site and Network the right to use the Sponsor Trademarks in connection with the Event, provided, however, that said right is nonexclusive, nonassignable and nontransferable. All proposed uses of the Sponsor Trademarks shall be subject to Sponsor's review and prior written approval.

\section{Closed Circuit Agreement.}

Prior to pay-per-view broadcast events, the premier boxing events (for example, Ali vs. Frazier in 1971, Leonard vs. Hearns in 1981, etc.) were sold to the public via closed circuit broadcast. The consumer would attend a movie theater or other public assembly location to view the live broadcast. In such circumstances, a closed circuit operator contracts from the promoter to receive the live broadcast rights in consideration for a license fee, and then charges an admission fee to the public to view the live broadcast. Pay-per view broadcast actually began in the 1970s in Ohio; however, the large scale marquee payper-view broadcast available for purchase from a consumer's home was introduced on April 12, 1991 when Evander Holyfield and George Foreman engaged in a world Heavyweight Championship Bout from Atlantic City. The Holyfield-Foreman pay-per-view broadcast recorded in excess of one million home buys. Pay-per-view broadcasts are now somewhat commonplace with regard to a variety of entertainment events, although the levels of commercial success (i.e., profits and losses) certainly vary.

Even today, and for live pay-per-view broadcasts, closed circuit rights exist (creating additional sources of revenue for the promoter) whereby licensees acquire the right to broadcast the pay-per-view event live at designated locations within a territory, e.g., bars, movie theaters, and restaurants. As with pay-per-view events (discussed in detail below), accounting and record keeping become important in confirming the accuracy of, and maximizing the amounts realized under these commercial arrangements. Moreover, a reality for promoters is that a larger percentage of the population is (illegally) acquiring so-called "black boxes" or "rate cards," whereby a pay-per-view event is viewed without cost. This practice is starting to have a substantial adverse effect on revenues associated with pay-per-view 
and closed circuit broadcast arrangements. This is similar to other forms of "pirating," for example in the music industry where songs are downloaded off the Internet for free, adversely affecting record label (and artist) revenues. Many promoters are now undertaking aggressive forms of surveillance activities in order to police, and potentially prevent, such pirating.

Promoter grants the right and license for the live exhibition of the Event solely on a closed circuit basis. The term "closed circuit basis" shall mean exhibition of the event at places of public assembly such as theaters, bars, clubs, lounges, restaurants and the like (capacity not to exceed 500 persons) whereby admission or other consideration may be charged or received, solely within the premises located within the Territory.

Promoter shall be responsible for delivery of the broadcast quality video and audio signal of the telecast of the Event. Licensee will provide at its expense a television satellite reception facility for each outlet and a signal decoder necessary to receive the video and audio signal of the Event telecast from the delivery point to the outlet.

Licensee shall remit to Promoter a fee of $\$ 125,000$, plus $15 \%$ of gross admission fees received by Licensee in connection with the closed circuit broadcast of the Event.

\section{PAY-PER-VIEW EVENTS}

It is widely acknowledged that in order for a professional boxer to reach marquee status he must become a pay-per-view broadcast attraction, requiring the boxing and (hopefully) general sports fan to actually pay to view the live televised boxing match. For most pay-per-view events commercial success is achieved by attracting not only the avid boxing fan but also the casual sports fan. For those events that have the good fortune to attract the boxing fan, the casual sports fan and the non-sports fan, rest assured that everyone involved will be smiling \ Monday morning as domestic pay-per-view revenues from the event begin to be tabulated.

There is a distinction between a marquee superstar boxer, and a professional boxer who possesses superstar talent. There are quite a few superstar talented professional boxers, yet only very few marquee boxers can attract a pay-per-view audience sufficient to warrant the time, expense and financial risk associated with the promotion of a pay-per-view broadcast.

The gurus in the pay-per-view broadcast industry are Jay Larkin of Viacom's Showtime PPV and Mark Taffet of AOL/Time Warner's HBO PPV, 
the respective pay-per-view arms of these media entities. This section provides general background information on the mechanics of a pay-per-view promotion as well as pro forma financial information of a pay-per-view event based on the assumptions illustrated below.

\section{The Deal.}

Depending on the particular event, the promoter either assumes financial risk in staging a pay-per-view event or (preferably) secures guaranteed sources of revenue to cover the projected expenses, including purses of the main event participants (generally the largest pay-per-view expense item). The risk arises because there are generally no guaranteed domestic live television revenues (such as a broadcast license fee from HBO or Showtime), but rather domestic television revenues are contingent upon pay-per-view home sales.

The promoter serves as the quarterback of the pay-per-view promotion and enters into various commercial arrangements and undertakes promotional, marketing, compliance, administrative and logistical responsibilities in promoting the event.

\section{a. Distribution Agreement.}

The promoter enters into a distribution agreement with the distributor of the event, such as Showtime PPV or HBO PPV. While not minimizing the comprehensive and sophisticated technical, marketing, and production efforts undertaken by these distribution entities, they are contractually charged with production responsibilities and marketing and distributing the event to cable operators throughout the United States and its territories. Such distribution by either Showtime PPV or HBO PPV is undertaken through pay-per-view affiliates and conduits (most notably, In Demand), enabling local cable operators such as Cablevision in New York City, Cox Cable in Las Vegas or Comcast in Chicago to have the event available for purchase by its regional subscribers. Accounting and record keeping issues are quite significant and certain promoters have retained accounting firms to audit the records provided by the cable operators and, ultimately, the distributor of the event to confirm the accuracy of the pay-per-view home sales report.

(1) Promoter hereby engages Distributor as:

(a) the sole and exclusive distributor of the PPV TV telecast of the Event throughout the Territory during the term of this Agreement, and 
(b) as the sole and exclusive distributor of the delayed telecast(s) ("Delay") of the Event during the period of time commencing as of March 13, 2004 and concluding upon the expiration of sixty (60) days following the conclusion of the Event.

(2) Distributor shall receive a Distribution Fee based on pay-per-view revenues (cash revenues received from pay-per-view territories and delayed telecasts) in an amount equal:

(a) $7.5 \%$ of the first $\$ 8.3$ million of pay-per-view revenues, plus

(b) $100 \%$ of pay-per-view revenues from $\$ 8.3-8.4$ million, plus

(c) $0 \%$ of pay-per-view revenues from $\$ 8.4-8.55$ million, plus

(d) $5 \%$ of pay-per-view revenues in excess of $\$ 8.55$ million.

\section{b. Other Agreements.}

As with any boxing promotion, the promoter enters into a site agreement with a venue, broadcast license agreements with international networks and cable stations throughout the world, sponsorship agreements, bout agreements with the boxers for their participation in the event, and a plethora of other insurance, travel, production and related vendor and consultancy agreements. Of particular note in a pay-per-view event is that the bout agreement for a main event participant may provide for the boxer to receive a base purse plus a variable financial upside based upon the number of pay-per-view home sales and corresponding domestic live television revenues to the promotion (e.g., $\$ 3 /$ per home in excess of 200,000 pay-per-view home sales).

\section{c. Sponsorship and Marketing.}

Many sponsors prefer to support a pay-per-view event as opposed to a cable or network televised event because there is a greater promotional and marketing effort put forward by the promoter, the distribution company and the boxers to "hype" the event. As noted above, domestic television revenues are variable as opposed to fixed and an aggressive marketing plan is created and implemented to enhance such event domestic broadcast revenues. Increased hype and marketing dollars means greater exposure to the public for the sponsor. When a boxing event is a pay-per-view broadcast and revenues are contingent upon consumers dialing up their regional cable operator and spending discretionary dollars, it is commonplace for the distributor and the promoter to also retain a public relations and marketing team specifically to create awareness for the event. 
The promoter and distributor jointly develop a marketing plan to enhance public and media awareness through the (hopeful) creation of compelling boxing matches and utilizing the demographic following of the event participants. For example, if one of the main event participants is a Latin boxer there will generally be a focused marketing plan in California, Texas and New York, of which pay-per-view data reflects a historic large Latin population supporting pay-per-view boxing. Promoters also endeaver to supplement the main event with undercard bouts that add diverse elements to attract a broader demographic following and the widest viewing fan base.

\section{d. Scheduling.}

Most large pay-per-view broadcasts are undertaken in the Spring and Fall for scheduling reasons and broadcast competition at that time (e.g., January Super Bowl, October World Series and March NCAA Basketball Tournament), the holiday season (the consumer is less likely to have discretionary dollars beginning in late November) and the vacation and social calendars of the average consumer (i.e., the summer months).

\section{The Economics of a Pay-Per-View Broadcast}

The following sets forth a theoretical example of the manner in which a pay-per-view promotion operates from a financial viewpoint. The principal variable, of course, is the number of homes that purchase the live broadcast of the event generating revenues available for distribution/allocation to the promoter and the boxers.

The following example assumes a pay-per-view broadcast that is estimated to generate between $150,000-200,000$ homes (reasonably successful by current standards). To provide a framework of these pay-per-view home sale estimates note the following pay-per-view event results:

- September 29, 2001 Bernard Hopkins vs. Felix Trinidad: 450,000 homes

- June 8, 2002 Lennox Lewis vs. Mike Tyson: 1,900,000 homes

- September 13, 2003 Oscar De La Hoya vs. Shane Mosley: 900,000 homes

- October 4, 2003 Evander Holyfield vs. James Toney: 130,000 homes

While there can be no assurances of what a particular event will generate in terms of pay-per-view home sales, there is precedent regarding particular boxers, the compelling nature of certain match-ups and other factors which the 
promoters, television executives, boxers and their representatives utilize in projecting the contemplated pay-per-view sales and retail pricing. Certain aspects, naturally, cannot be forecasted, such as current events at the time, the economy, weather, etc.

The following is a broad based budget for a pay-per-view event, which is not inclusive of all categories inherent in a pay-per-view broadcast but does address the general revenue and expense categories associated with the promotion of a pay-per-view event:

\section{Revenues:}

Live Gate ${ }^{6}$

Delayed Broadcast

$\$ 850,000$

Net PPV (based on 200,000 homes- see below)

Closed Circuit

Sponsorship

Net International Sales ${ }^{7}$

750,000

$3,700,000$

100,000

75,000

300,000

Total Revenues

$\$ 5,775,000$

Expenses:

Main Event Purses ${ }^{8}$

$\$ 3,500,000$

Undercard Purses

600,000

Marketing Budget

800,000

Other Expenses

250,000

6. Such amount reflects the gross live gate, and the promoter would be responsible for athletic commission and related State/City taxes associated with the live gate revenue. A promoter upside based on net receipts from gate revenues may be incorporated into the site agreement.

7. There are many agents and subagents in various territories throughout the World to whom commissions are paid in generating international sales. Generally a commission in the range of $10 \%$ $20 \%$ is paid to such agents in order to secure the license fee from networks within the various international territories. In certain instances, one consolidator is granted the license to sell throughout the World, and in other instances a promoter may farm out the international sales through more than one agent based upon their relative strengths within select territories.

8. This is the base purse and does not include potential upside for the main event participants relating to pay-per-view home sales. 
[Event Hotels \& Meals, Staff \& Production, Press Tours \& Related Travel, Insurance, Bank Fees, Production Budget, Public Relations, Live Gate Promotion, Consultants, Domestic/International Production, TV Taxes/Athletic Commission, Promoter License Fees, Sanction Fees, Ring Announcer and Miscellaneous]

Total Expenses

Net Profit (Loss)
$\$ 5,150,000$

$\$ 625,000$

The following provides explanatory information on the above Budget:

a. Revenues

\section{i. Live Gate. $\$ 850,000$.}

While not always symmetrical, for a pay-per-view broadcast expecting approximately 200,000 home buys, $\$ 850,000$ is a reasonable assessment of the live gate. In comparison, the June 8, 2002 Lewis vs. Tyson bout (1.9 Million PPV) and the October 4, 2003 Holyfield vs. Toney bout (130,000 PPV) generated gross live gate revenues of approximately $\$ 13$ million and $\$ 2.5$ million, respectively. The Holyfield vs. Toney bout reflects that pay-per-view home sales and live gate revenues do not always have an economic correlation.

ii. Delayed Broadcast. $\$ 750,000$.

This is what a premium cable network such as HBO or Showtime may pay to the promoter to broadcast the event on a delayed basis, commencing generally one week following the date of the live pay-per-view event on their pay-per-view affiliate. Secondary delay broadcasts on television outlets such as ESPN, FOX SportsNet or Univision may also be available in exchange for substantially lower delay broadcast fees, or more likely as a barter arrangement to promote/market the pay-per-view event on their cable network leading up to the event. 
iii. Closed Circuit. $\$ 100,000$.

This represents the closed circuit rights within the United States, such as movie theaters, bars and other closed circuit outlets and is typically consolidated by the promoter through one closed circuit operator who guarantees the promoter a fixed fee and then sells the event throughout the country to its cable network of bars, theaters, etc.

\section{iv. International Sales. $\$ 300,000$.}

This is an area where there are tremendous variables and, as noted above, many agents and subagents involved. With regard to international sales many promoters "package" international sales whereby they sell a fixed number of events to networks within various countries on an annual basis and allocate the gross license fees over a number of events staged by the promoter. It is necessary to review on a country by county basis the revenues for the particular event so that the boxer does not get penalized from such packaging arrangement.

\section{v. Sponsorship. $\$ 75,000$.}

This is generally based upon a beer company and selling of the ring mat and the ring posts together with corresponding signage. Many sponsorship arrangements in a pay-per-view broadcast include a combination of a cash component paid by the sponsor and a barter arrangement whereby the sponsor includes the pay-per-view event in its own product advertising.

\section{vi. Domestic Television.}

As noted above, the domestic broadcast fee is a variable based upon the number of pay-per-view homes for the particular event. Assuming a pay-perview retail price of $\$ 39.95$, and following deduction of (a) the percentage of such pay-per-view price to the cable operator (generally $50 \%$ of retail price goes to the local cable operator although such percentage differs based upon the marketability of the event and the desire of the cable company to possess the ability to sell the event to its local cable subscribers) and (b) the approximate $7.5 \%$ distribution fee remitted to the distributor (Showtime PPV 
or HBO PPV as discussed above), the promoter receives approximately $\$ 18.50$ from each home purchase comprising the domestic television fee.

The following chart is based upon the number of pay-per-view home sales and the corresponding net $\$ 18.50$ per home pay-per-view revenues realized by the promoter in this example:

\begin{tabular}{|l|l|}
\hline $\begin{array}{l}\text { NUMBER OF PAY-PER-VIEW HOME } \\
\text { SALES }\end{array}$ & $\begin{array}{l}\text { NET PAY-PER-VIEW REVENUES TO } \\
\text { PROMOTION (ROUNDED) }\end{array}$ \\
\hline 75,000 Homes & $\$ 1.4$ million (@ \$18.50/per home) \\
\hline 100,000 Homes & $\$ 1.85$ million \\
\hline 150,000 Homes & $\$ 2.8$ million \\
\hline 200,000 Homes & $\$ 3.7$ million \\
\hline 250,000 Homes & $\$ 4.6$ million \\
\hline 300,000 Homes & $\$ 5.5$ million \\
\hline
\end{tabular}

There are various aspects of a pay-per-view promotion which require a knowledge of boxing industry personnel, legal and commercial considerations and sophisticated assessments of the results that can be reasonably expected from a pay-per-view broadcast, justifying the enhanced expense, time and commercial risk necessary to stage and promote such an event. The above does not cover all of the intricacies of a pay-per-view broadcast and is not intended in any manner to minimize the enormous effort that is undertaken by literally hundreds of people in order to achieve a successful pay-per-view event.

\section{E. SUMMARY}

Professional boxing has been around for centuries, and is likely to continue for many years to come. While not considered within the mainstream of sports, the substantial dollars, glorified history and the "electricity" that is generated at a major World Championship Boxing event is arguably 
unparalleled by any other sporting event. It is also acknowledged that the economics associated with professional boxing are being adversely affected by many factors, including the saturation of pay-per-view broadcasts, reduced budgets at the premium cable networks and a fan base that is being affected by the controversy and perceived abuses within the boxing industry, such as mismatches within the ring or corrupt activities outside of the ring. Despite these many challenges, professional boxing is a sport that will endure.

This essay intended to address in a broad overview manner various legal and commercial considerations inherent within the boxing industry. While legislation has been enacted to try and prevent certain of the abuses referenced above, federal governance may not be the answer and the sport needs some form of overhaul in order for those involved in the industry to prosper, let alone to financially survive. Currently, very few financially prosper in boxing at each and every level of the industry. Efforts are being undertaken with regard to the potential establishment of a governing body, similar to The Office of the Commissioner in Major League Baseball, the National Football League and the National Basketball Association. Whether boxing is too splintered in order to achieve such uniformity of rules, regulations and legal considerations is still to be determined, but is likely essential.

\section{ABOUT THE AUTHOR}

JEFFREY S. FRIED is an attorney and certified public accountant, who has practiced for eighteen years in the areas of corporate finance and sports and entertainment law. In 1994 he established Fried \& Company, P.C., a Washington, D.C. based law firm comprised of attorneys, management personnel, and other professionals specializing in the representation of corporate interests, athletes, entertainers, media interests and the commercial and legal aspects of sports and entertainment events. Mr. Fried is also a member of the National Attorneys General Task Force on Boxing Reform.

\section{REFERENCES}

CAL. LAB. CODE $\S 2855$ (a) (2003).

Don King Productions, Inc. v. Douglas, 742 F. Supp. 741 (S.D.N.Y. 1990a).

Don King Productions, Inc. v. Douglas, 742 F. Supp. 778 (S.D.N.Y. 1990b).

Graciano Rocchigiani v. WBC, Inc., 131 F. Supp. 2d 527 (S.D.N.Y. 2001).

Ketcham v. Hall Syndicate, 37 Misc.2d 693 (N.Y. Gen. Term 1962). 
Lewis v. Rahman, 147 F. Supp. 2d 225 (S.D.N.Y. 2001).

Muhammad Ali Boxing Reform Act, 15 U.S.C. $\$ 6301$ et. seq. (2000).

Nevada Administrative Code, Unarmed Combat, $§ 467$ (2003).

Oscar De La Hoya v. Top Rank, Inc., CV 00-9230-WMB, at 1 (C.D. Cal. 2001). Rooney v. Tyson, 91 N.Y.2d 685 (N.Y. 1998).

United States v. Robert W. Lee, CR 99-640 (D. N.J. 2001). 


\section{ANNEX A}

Required Disclosures by Promoter to Boxer

(as required by Section 13 of the Muhammad Ali Boxing Reform Act)

Name of Boxer:

Date of the Event:

Location of the Event:

As the Promoter for the above named event has received the following compensation or consideration resulting from your match:

ITEM

Site Fee

Domestic Television Revenue

Sponsorship

International Television Broadcast

Other (describe)

\section{AMOUNT RECEIVED RECEIVED FROM}

Boxer

Promoter

Date

Required Disclosures by Promoter to Boxing Commission (as required by Section 13 of the Muhammad Ali Boxing Reform Act)

Name of the Promoter:

Date of Event:

Location of the Event:

As the Promoter of the above event, affirms that the following has been provided to the applicable Athletic Commission: 
A copy of any and all Agreements in writing that , as the Promoter, has with any Boxer participating in the match, and that there are no other agreements written or oral, between or the Boxer with respect to the above named event. This shall include any reduction in a Boxer's purse that is contrary to any previous agreement between the Boxer and - Also, set forth below is a listing/description of any active and binding agreements with the Boxer other than those attached for this particular bout.

As the Promoter of the above event, the following represents all charges, fees and expenses that will assess, including any training expenses, on the following Boxers and any portion of the Boxers' purse that includes only Boxers that will receive. This list is taking a share of the Boxer's purse.

Name of Boxer

1.

2.

3.

4.

5.

. 4.

.
All costs that will be assessed on this Boxer

See Attached

Payment Breakdown is assessing costs to and/or whereby also hereby affirms that 
3. World Boxing Association

4. World Boxing Organization

The undersigned hereby affirms that the statements made herein are true and correct to the best of information, knowledge and belief, and are made subject to the penalties prescribed for perjury set forth in (the applicable codes).

By: Authorized Representative 


\title{
ANNEX B
}

\author{
NEVADA ATHLETIC COMMISSION
}

\section{OFFICIAL BOUT AGREEMENT}

THIS AGREEMENT, Made this , by and between , (state)

day of

, a promoter of unarmed combat, duly

licensed under the laws of the State of Nevada (whether one or more, individually, or as an association, hereinafter referred to as the "Promoter"), and _ of (city) , (state) professional unarmed combatant ("Contestant"), and of (city), (state) , a duly license manager under the laws of the State of Nevada (whether one or more, hereinafter referred to as the "Manager").

WITNESSETH:In consideration of the mutual covenants and agreements hereinafter contained, the parties hereto agree to and with each other as follows:

1. Definitions. In this agreement, the words and terms used herein, unless the context otherwise requires, shall have the meanings ascribed to them in Nevada Revised Statutes ("NRS") and Nevada Administrative Code ("NAC") Chapter 467.

2. Appearance of Contestant. The Contestant will appear and enter into a contest of unarmed combat at the site location of , Nevada on the

or on a date to be hereafter agreed upon, for day of with of rounds to a decision opponent, at a weight not over pounds, said weight to be taken on the certified scales of the Promoter (this contest is hereinafter referred to as the "Bout").

3. Compensation of Contestant. The Promoter will pay the Contestant for the Bout, and the Contestant agrees to accept in full of all claims and demands for his services and the performance by him or her of the 
Bout, the sum of (the "Compensation").

Dollars $(\$$

4. The Bout. The Bout shall be conducted in all respects in conformity with the laws of the State of Nevada, and the rules and regulations of the Nevada Athletic Commission (the "Commission"), which are hereby made a part of this agreement. The referee of the Bout shall be licensed to act as such by the State of Nevada, and selected and assigned to act as a referee of the Bout by the Commission.

5. Reporting Time. The Contestant shall personally report at the above-named site location for weighing and medical examination, in accordance with the rules and regulations of the Commission, and shall report at the site to the Executive Director two (2) hours before the time set for the contest.

6. Publicity. The Contestant agrees to appear when and as directed by the Promoter at all reasonable times for publicity purposes.

7. Payment of Manager's Share. Should the Contestant desire the Manager to be paid directly by the Promoter, deducting such amount from the Contestant's share of the purse (a) the Manager must be licensed by the Commission, (b) a valid contract between the Contestant and the Manager must be on file with the Commission, (c) the amount to be paid to the Manager must not exceed one-third of the compensation, and (d) the contestant must specify and initial any such amount below. $\%$ INITIALS OF CONTESTANT

8. Breaches of this Agreement. The following acts or omissions constitute a breach of this agreement if the Commission shall decide that (a) The Contestant and the Manager, or either of them, did not enter into this agreement in good faith; (b) The Contestant and the Manager, or either of them, had any collusive understanding or agreement regarding the termination of the Bout other than that the same should be on an honest exhibition of skill on the part of the contestants; (c) The Contestant is not honestly competing or did not give an honest exhibition of his or her skill; or (d) The Contestant, the Manager and the Promoter, or any of them, is guilty of an act detrimental to the interest of unarmed combat or is guilty of violating any provision of NRS/NAC Chapter 467 . 
9. Agreements in the event of a Breach. The parties agree that if the Commission of its Executive Director determines that the possibility of a breach of this agreement exists, as set forth in Section 8 of this agreement, the Commission or its Executive Director, in their discretion, may order that the Promoter or any person holding the Compensation, to pay the Compensation directly to the Commission. The parties hereby waive any right or claim to a hearing on this matter. The Commission shall thereupon, in its sole discretion, make such a disposition of the Compensation as it deems to be in the best interest of unarmed combat, subject to the provisions of NRS/NAC Chapter 467. The parties agree and understand that if the Commission or its Executive Director determines that the possibility of a breach exists, as set forth in Section 5 of this agreement, that no part of the Compensation shall be distributed unless so ordered by the Commission after a hearing held in accordance with NRS/NAC Chapter 467.

INITIALS OF PARTIES (P)

10.Applicable Law. It is understood and agreed that the rights and obligations of the parties hereto shall be governed by, and construed according to the laws of the State of Nevada. The terms of this agreement shall in all respects be in conformity with the laws of the State of Nevada, and the rules and Regulations now or hereafter adopted by the Commission, which laws and rules are hereby made a part of and incorporated into this agreement. It is agreed by all of the parties that any action arising out of this agreement, shall be commenced in the State of Nevada.

11.Assumption of the Risk. The Contestant understands that by participating in a contest of exhibition of unarmed combat, that the Contestant is engaging in an abnormally dangerous activity. The Contestant further understands that his participation subjects the Contestant to a risk of severe injury or death. The Contestant, with full knowledge of this risk, nonetheless, agrees to enter into this agreement and hereby waives any claim that the Contestant or Contestant's heirs may have against the Commission and/or the State of Nevada as the result of any injury the Contestant may suffer as a result of Contestant's participation in any contest of exhibition of unarmed combat in the State of Nevada.

INITIALS OF CONTESTANT 
12.Release. The parties, for themselves, their heirs, executives, administration, successors, and assigns, hereby release and forever discharge the State of Nevada and the Commission, and each of their members, agents, and employees in their individual, personal and representative capacities, from any and all action, causes of action, suits, debts, judgments, execution, claims and demands whatsoever known or unknown, in law or equity, that the parties ever had, now have, may have, or claim to have against any and all of the persons or entities named in this paragraph arising out of, or by reason of this agreement, or any other matter.

13.Indemnification. The parties, jointly and severally hereby indemnify and hold harmless the State of Nevada and the Commission, and each of their members, agents, and employees in their individual, personal and representative capacities against any and all claims, suits and actions, brought against the persons named in this paragraph by reason of this agreement and all other matters relating thereto, and against any and all expenses, damages, charges and costs, including court costs and attorney fees which may be incurred by the persons and entities named in this paragraph at a result of said claims, suits and actions.

14.Entire Agreement and Modification. This agreement constitutes the entire agreement of the parties and as such are intended as a complete and exclusive statement of the promises, representations, negotiations, discussions, and other agreements that may have been made in connection with the subject matter hereof. All prior agreements are superseded and excluded. Unless expressly authorized by the terms of this agreement, no modification or amendment to this agreement shall be binding upon the parties unless the same is in writing signed by the respective parties hereto, and filed with the Commission.

15.Proper authority. The parties hereto represent and warrant that the person executing this agreement on behalf of another party, if applicable, has the full power and authority to enter into this agreement.

16.Severability. If any provision in this agreement is held to be unenforceable by a court of law or equity, this agreement shall be construed as if such provision did not exist and the nonenforceability 
of such provision shall not be held to render any other provision or provisions of this agreement unenforceable.

17.Notices. All notices or other communications required or permitted to be given under this agreement shall be in writing and shall be deemed to have been duly given if delivered personally in hand, by telephonic facsimile or mailed regular or certified mail to the appropriate party at the last known address on record with the Commission. It is understood by the parties that it is the responsibility of each party to notify the Commission of any change of address.

18. Waiver of Breach. Failure to declare a breach or the actual waiver of any particular breach of the agreement or its material or nonmaterial terms by either party shall not operate as a waiver by such party of any of its rights or remedies as to any other breach.

19.Assignment. Neither party shall assign, transfer nor delegate any rights, obligations or duties under this agreement without the prior verbal or written consent of the Commission or the Executive Director of the Commission.

IN WITNESSETH WHEREOF, the parties hereto affix their signatures on the date indicated.

\section{PROMOTER}

By (Signature) Date:

Date:

MANAGER Date:

NOTICE TO MATCHMAKER: Each contestant MUST BE SIGNED on this Official Bout Agreement. The original Bout Agreement MUST be submitted by weigh in time to the Commission.

Managers handling contestants under so-called "verbal agreements" cannot sign contracts for contestant's appearance as verbal agreements are not recognized by the Commission. If a contestant has no written agreement with a licensed manager, the contestant must sign his or her own Bout Agreement. 